1 Department of Operative Dentistry, Endodontics and Dental Materials, Bauru School of Dentistry,

University of São Paulo, Bauru, São Paulo, Brazil.
Corresponding author:

Genine Guimarães

Email: genine_mg@hotmail.com

Received: April 29, 2020

Accepted: December 14, 2020

\section{Dentin bond strength evaluation between a conventional and universal adhesive using etch-and-rinse strategy}

\author{
Genine Moreira de Freitas Guimarães ${ }^{1, *}$ (iD, Karin \\ Cristina da Silva Modena ${ }^{1}$ (iD, Carolina Yoshi Campos \\ Sugio $^{1}$ (iD), Tamires de Luccas Bueno' (iD, Maria \\ Angélica Silvério Agulhari ${ }^{1}$ (iD, Maria Teresa Atta ${ }^{1}$ (iD
}

Aim: The aim of this study was to compare the microtensile bond strength ( $\mu \mathrm{TBS}$ ) and the characteristics of the adhesive interface of Scotchbond Universal - SU - etch-and-rise mode (3M ESPE) and Adper Scotchbond Multi-Purpose MP (3M ESPE) to dentin over time. Methods: Class I cavity preparations were performed in 60 human molars that were randomly divided according to the dentin bonding system (DBS) used ( $n=30)$ : (1) Acid conditioning + SU and (2) Acid conditioning + MP. For bonding strength (BS) analysis, 30 teeth $(n=15)$ were sectioned into sticks and submitted to the microtensile test in a universal testing machine after 24 hours and 12 months. The adhesive interface of the others 30 teeth was analyzed in a confocal microscope after 24 hours and 12 months. The data of $\mu$ TBS were analyzed by two-way repeated measures ANOVA and Tukey's HSD (a $=0.05$ ). Results: SU presented the lowest DBS compared to MP $(p=0.000)$. Time did not influenced DBS for both adhesive systems $(p=0.177)$. Confocal microscopy analysis showed no cracks between both adhesive systems tested. Conclusion: The results indicate that MP - $\mu$ TBS showed a better performance compared to SU in total-etch mode.

Keywords: Dentin-bonding agents. Dentin. Methacrylates. Microscopy, confocal. 


\section{Introduction}

Since the introduction of the adhesive systems, over 50 years ago, the union interface to dentin remains the weakest link in restorative treatment ${ }^{1-4}$. Although many studies have shown excellent short-term and immediate adhesion effectiveness ${ }^{5,6}$, the durability and stability of the adhesive interface on dentin remain questionable $e^{7,8}$ due to its inherent characteristics. The failure of adhesion may lead marginal infiltration, which may cause discoloration, secondary caries, and subsequent loss of retention ${ }^{3,9,10}$. In order to minimize adhesive failures, universal adhesives have become a trend in dentistry due to its effectiveness and longevity, and a simplified operative technique.

Conventional three-step adhesive systems are considered the "gold standard". However, as a disadvantage, if all the collagen exposed after acid etch is not completely covered by the adhesive systems, matrix metalloproteinases (MMPs) are activated, when they have free access to water, causing restoration failures and post-operative sensitivity $8,11,12$

The first simplified adhesive system "one bottle" introduced on the market was the Scotchbond Universal (SU) adhesive (3M ESPE, Saint Paul - MN, USA), which can be used as an etch-and-rinse or a self-etch mode ${ }^{13,14}$, according to the clinical conditions. The self-etch mode eliminate previous application of phosphoric acid, that is a sensitive part of the technique. Thus, acid monomers have the ability to demineralize and penetrate the dentin substrate simultaneously, decreasing the chances of demineralized zones without hybridization, as can happen in etch-and-rinse mode ${ }^{15}$. However, the different applications of SU (etch-and-rise and self-etch mode) show different behaviors and reflect on the bond strength and quality of the hybrid layer ${ }^{16-19}$.

The difference from SU to the others adhesive systems is the substitution of methacrylate monomers (UDMA and GDMA) or phosphorylated methacrylate monomer (MHP) by 10-methacryloyloxydecyl dihydrogenpho-sphate (10-MDP) 15,18,20-23. Functional monomers, such as 10-MDP, contain carboxylic groups and phosphates that are capable of chemically interact with the calcium of the hydroxyapatite by means of primary ionic bonds, forming stable salts of calcium-phosphate and calcium-carboxalate together with a limited effect of descaling ${ }^{24}$. The chemical adhesion promoted by 10-MDP seems to be not only effective but also more stable in water than that promoted by other functional monomers such as 4-MET and phenyl $\mathrm{P}^{23}$.

Despite the favorable chemical reaction from MDP, the factors that interfere with the longevity of the bonding interface are still complex. There are several mechanisms that favor the degradation of the hybrid layer. One of the most relevant factors is related to simplified adhesive systems that have hydrophilic characteristics ${ }^{25-27}$. In addition, there is a big difference in $\mu$ TBS for SU when used in the etch-and-rise or self-etch strategy ${ }^{9-16}$.

Therefore, the objective of this study is to evaluate the difference between mechanisms of adhesion and to compare the dentin bonding system (DBS), as well as to evaluate the characteristic of the bonding interface between a universal and a conventional three-step adhesive system with using etch-and-rise mode. 
The null hypothesis of this study is that both DBS evaluated did not show differences between the adhesives and through the time.

\section{Material and Methods}

\section{Specimens preparation}

Sixty sound human molars with no fracture, cracks or caries lesions extracted due to periodontal or orthodontic reasons were used according to the protocol of Ethics and Research Committee of the Bauru School of Dentistry, University of São Paulo (CAAE $n^{\circ}$ 336.286). Teeth were cleaned removing any residue of periodontal and gingival tissues adhered to the dental surface with manual curettes and stored in a $0.1 \%$ thymol solution at room temperature for less than 6 months. Using a low-speed diamond saw (Isomet Low Speed Saw; Buehler Ltda., Lake Bluff/IL - EUA) under water lubrication, the crowns were separated from the roots. Class I cavities ${ }^{28-34}$ were prepared 4.0 $\mathrm{mm}$ deep in dentin, with $3.0 \mathrm{~mm}$ buccal extension and $5.0 \mathrm{~mm}$ mesiodistal extension using carbide drills (\#245, KG Sorensen).

\section{Microtensile bond strength test ( $\mu$ TBS)}

\section{Bonding procedures}

The experimental unit considered was the tooth, so the sticks of each tooth $(n=30)$ were randomly divided according to DBS (n=15): 1 - SU or 2 - MP using Excel's "randomization" tool.

Each Class I cavity were etch-and-rinse with 35\% phosphoric acid etchant (Condac, FGM, Brazil) for 30s (enamel) and 15s (dentin). The two adhesives (SU and MP) were carefully applied according to the manufacturer's instructions (Table 1). All teeth were restored by incremental technique with Filtek ${ }^{\text {TM }}$ Z250 resin composite (3M ESPE, Saint Paul - MN, USA) and photoactivated for 40 s with $1200 \mathrm{mV} / \mathrm{cm}^{2}$ of irradiation (Radii-cal ${ }^{\circledR}$, $\mathrm{SDI}$ SP, Brazil). After the restorative procedures, the specimens were immersed in deionized water at $37^{\circ} \mathrm{C}$ for $24 \mathrm{~h}$ or 12 months, according to the tested group.

Table 1. Adhesive systems: composition and protocol.

\begin{tabular}{|c|c|c|}
\hline Material & Composition & Protocol \\
\hline $\begin{array}{l}\text { Adper Single Bond } \\
\text { Universal (SU) } \\
(\mathrm{n}=15) \\
\text { 3M ESPE } \\
\text { Saint Paul - MN, USA }\end{array}$ & $\begin{array}{l}\text { 10-MDP phosphate } \\
\text { monomer, Vitrebond } \\
\text { Copolymer HEMA } \\
\text { BISGMA, dimethacrylate } \\
\text { resins Filler, silane, } \\
\text { initiators Ethanol, water }\end{array}$ & $\begin{array}{l}\text { 1. Acid etch (Scotchbond Etchant } 35 \% \text { - Condac, FGM, } \\
\text { Brazil) of the enamel for } 30 \text { s and dentin for } 15 \text { s followed } \\
\text { by washing with "spray" air/water for } 30 \text { s. Excess water } \\
\text { removed with absorbent paper. } \\
2 \text {. Application of the adhesive for } 20 \text { s with slight } \\
\text { movements with the application applicator. Light dry with } \\
\text { air for } 5 \text { s to evaporate the solvent. Polymerization for } 10 \text { s. }\end{array}$ \\
\hline $\begin{array}{l}\text { Adper Scotchbond } \\
\text { Multi-Purpose (MP) } \\
(\mathrm{n}=15) \\
\text { 3M ESPE } \\
\text { Saint Paul - MN, USA }\end{array}$ & $\begin{array}{l}\text { Primer: HEMA, } \\
\text { polyalkanoic acid } \\
\text { copolymer, water } \\
\text { Adhesive: Bis-GMA, } \\
\text { HEMA, Camphorquinone }\end{array}$ & $\begin{array}{l}\text { 1. Acid etch (Scotchbond Etchant } 35 \% \text { ) of the enamel } \\
\text { for } 30 \text { s and dentin for } 15 \text { s followed by washing with } \\
\text { "spray" air/water for } 30 \text { s and removing excess water with } \\
\text { absorbent paper. } \\
\text { 2. Application of a primer layer and light drying for } 5 \mathrm{~s} \\
\text { 3. Application of the adhesive and polymerization for } 10 \text { s. }\end{array}$ \\
\hline
\end{tabular}




\section{Bonding test}

The restored teeth were sectioned buccal-lingually into slices with a double-sided diamond disc (Extec Corp., Enfield / CT - USA), cooled with deionized water, at a 150 rpm speed in a sectioning machine (Isomet Low Speed Saw; Buehler Ltda., Lake Bluff / IL - USA). Subsequently, each slice was cutted into sticks with a cross-sectional area of approximately $0.64 \mathrm{~mm}^{2}$ that were separated into 2 groups according to the test period: $24 \mathrm{~h}$ (baseline) and 12 months and stored in water at $37^{\circ} \mathrm{C}$ with frequent water exchange.

After the storage, each stick was individually fixed with cyanoacrylate-based adhesive (Loctite Super Bonder Flex Gel, Henkel Ltda., São Paulo/SP - Brazil) in a Bencor Multi-T device (Danville Engeneering, Danville/CA - USA) and submitted to the microtensile test in a universal testing machine (Instron Model 3342, InstronCorp., Canton, MA) at a constant speed of $0.5 \mathrm{~mm} / \mathrm{min}$, with maximum load of $500 \mathrm{~N}$.

The Mann Whitney test was realized and the results were analyzed by two-way repeated measures ANOVA and Tukey's HSD $(a=0.05)$. The average $\mu$ TBS value for each tooth and time based on all the sticks was calculated and the premature failures were considered as zero for calculating the mean values.

\section{Analysis of the adhesive interface - confocal laser scanning microscopy}

The remained 30 teeth were prepared as describe above, but the adhesive systems were labeled with rhodamine B $(0.02 \mu \mathrm{g} / \mathrm{mL} \text { for SU and } 0.1 \mu \mathrm{g} / \mathrm{mL} \text { for } \mathrm{MP})^{35}$, in order to allow the analysis of the micromorphology of the adhesive interface with greater accuracy.

A confocal laser scanning microscopy (Leica TCS SPE, Leica Microsystems CMS, Mannheim, Germany) at 40X magnification microscopy software (Leica Application Suite Advanced Fluorescence, Leica Microsystems CMS) (1.0 mm, 1024 pixels and $0.976 \mu \mathrm{m}$ in resolution) was used to evaluate the quality of the hybrid layer, through the analysis of the presence or absence of cracks after storage in water at $37^{\circ} \mathrm{C}$ for $24 \mathrm{~h}$ and 12 months. As it is a qualitative evaluation, no statistical analysis was performed.

\section{Results}

\section{Microtensile bond strength ( $\mu$ TBS) test}

The means and respective standard deviations of bond strength (MPa) in the periods of 24h (baseline) and 12 months are shown in Table 2. Only DBS was a statistically significant factor $(p=0.000)$. Non-significant differences were detected in the microtensile bond strength among the adhesives tested and the periods evaluated $(p=0.1772)$ as well as the interaction DBS/time $(p=0.570)$. MP DBS presented the highest values of BS. Both adhesives were able to maintain DBS after 12 months. Fracture analysis revealed that the most predominant failure pattern was 'adhesive'. The fracture pattern of each specimen (stick) was evaluated and the results obtained are listed in Table 3. 
Table 2. Means and standard deviations of tested groups (MPa).

\begin{tabular}{lcc}
\hline Adhesives & Baseline $(24 \mathrm{~h})$ & 12 months \\
\hline SU & $24.09 \pm 8.46 \mathrm{Ab}(\mathrm{n}=15)$ & $22.58 \pm 7.35 \mathrm{Ab}(\mathrm{n}=13)$ \\
\hline MP & $29.96 \pm 9.76 \mathrm{Aa}(\mathrm{n}=15)$ & $28.09 \pm 11.54 \mathrm{Aa}(\mathrm{n}=15)$ \\
\hline
\end{tabular}

Different uppercase letters indicate differences between time (columns) $(p \leq 0.05)$. Different lowercase letters indicate differences between $\mu$ TBS (rows) $(p \leq 0.05)$.

Table 3. Type of fracture in each group.

\begin{tabular}{lcccc}
\hline Type of fracture & \multicolumn{2}{c}{ Baseline (24h) } & \multicolumn{2}{c}{ 12 months } \\
\hline Adhesive & $\mathbf{n}$ & $\mathbf{( \% )}$ & $\mathbf{N}$ & (\%) \\
\hline Mixed & 33 & 44.59 & 27 & 51.92 \\
\hline Cohesive in resin & 28 & 37.83 & 19 & 36.53 \\
\hline Cohesive in dentin & 11 & 14.86 & 4 & 7.69 \\
\hline Total & 2 & 2.70 & 2 & 3.84 \\
\hline
\end{tabular}

There was no statistical significant difference between (significance level of $5 \%$ ).

\section{Adhesive interface analysis (Hybrid Layer Quality - Confocal Microscopy)}

The results showed that at $24 \mathrm{~h}$ and 12 months, no difference was observed between the two adhesive systems SU and MP. No gaps were observed at the bonding interface (Figure 1).

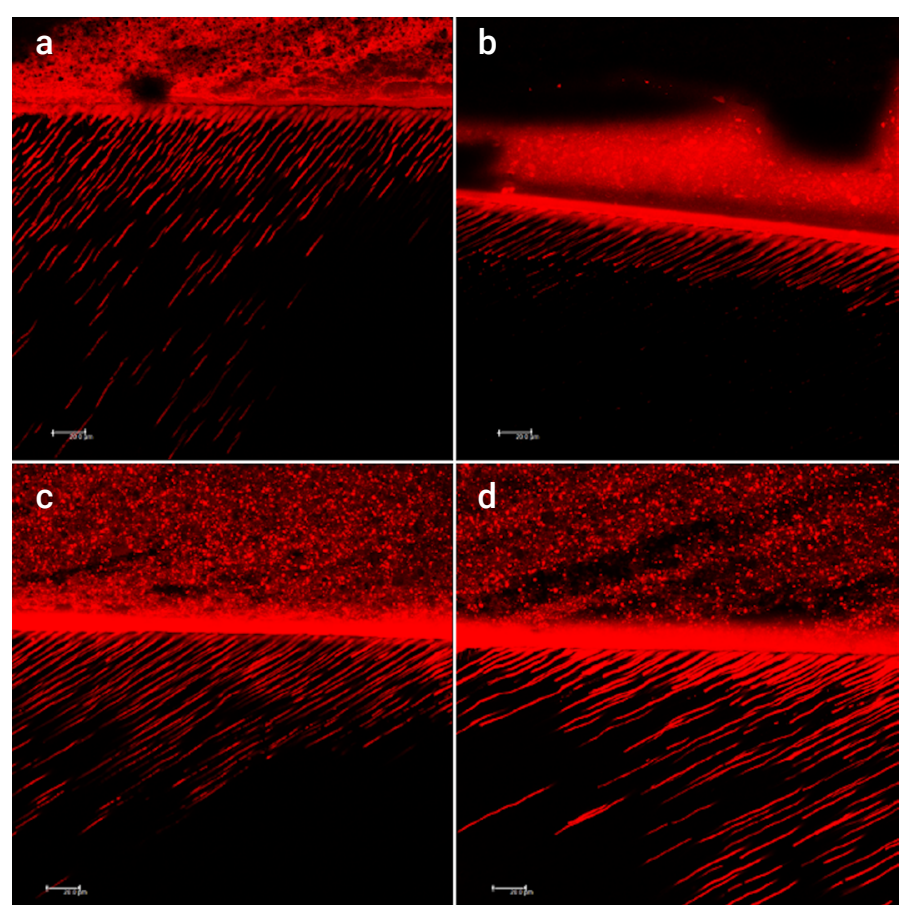

Figure 1. Confocal Microscopy images show the hybrid layer with no gaps at all periods observed. a) 24h-SU; b) $24 \mathrm{~h}-\mathrm{MP}$; c) 12 months-SU; d) 12 months-MP. 


\section{Discussion}

The microtensile bond strength test is frequently performed to evaluate in vitro adhesive systems. This study compared the $\mu$ TBS of dentin, using a universal (SU) and a conventional adhesive (MP) in the etch-and-rinse mode. This study also evaluated the quality of the bonding interface of both adhesive systems in a confocal microscopy. The proposal was to observe the behavior of SU and MP adhesives under similar conditions.

The specimens were obtained from Class I cavities, representing high C-factor which influence the values of $\mu \mathrm{TBS}^{29,31-33,36}$. Specimens obtained from cavities showed a statistically significant reduction in bond strength values due to the high $\mathrm{C}$-factor ${ }^{32}$. So, the objective was to evaluate the behavior of those adhesives in an extremely situation ${ }^{28-34}$. Also was performed Class I cavities because, unlike posterior restorations, non-carious cervical lesions usually have sclerotic dentin and could reflect different results ${ }^{37}$. Studies show that cavities with low C-factor, as in non-carious cervical lesions, have underestimated values compared to values presented clinically, as it appears in Class I cavities $^{32}$, and the reliability of dentin adhesives is dependent upon the quality of the dentin ${ }^{36}$.

Another factor to consider is the presence of enamel on the cavity margins, which theoretically provides a good seal against the ingress of bacteria and oral fluids and thus protects the most vulnerable adhesive bonding of the underlying dentin ${ }^{16,38}$. Without enamel protection on the periphery of the restoration, water promotes adhesive interface degradation resulting in decreased bond strength over time ${ }^{16,25,39}$. This was considered mainly because of the 12 months specimens.

With the limitations of this study, the $\mu$ TBS results showed that the MP values was significantly higher compared to SU, with no significance between the two times tested. Besides the Universal Single Bond promotes chemical bonding to the hydroxyapatite crystals present on the enamel and dentine ${ }^{6,40,41}$, some authors claim that there are no differences in the performance of adhesive systems containing 10-MDP ${ }^{13}$. One hypothesis suggests that prior acid etch may remove hydroxyapatite and hinder chemical bonding, which is the main benefit of MDP. In contrast, Hidari et al. ${ }^{42}$ (2020) show that the presence of the functional monomer MDP, even with previous phosphoric acid conditioning, produces greater bond strength results in dentin than the absence of this functional monomer ${ }^{19,42,43}$. However, it is concluded that although the functional monomer MDP has an important role in the quality of the bonding interface, the removal of the smear layer and hydroxyapatite through prior acid conditioning can be disadvantageous related to the long-term bond strength durability.

A systematic review with meta-analysis concluded that universal adhesives with etchand-rinse strategy is more effective and produces higher values of $\mu$ TBS in enamel ${ }^{44}$, and, on dentin, self-etch mode can produce better values ${ }^{18,45,46}$. However, in this study, the SU was used only with the etch-and-rinse strategy and can explain the results of the present study which showed lower statistical values (22.58 \pm 7.35$)$ compared to MP (28.09 \pm 11.54$)$.

The quality of the hybrid layer is necessary to prevent microleakage and gap formation $^{47}$. Therefore, the confocal interface analysis supported the $\mu$ TBS data. Regarding the interface durability of both adhesives tested, there were no statistical differences 
on $\mu$ TBS in the two periods tested (24h and 12 months). This shows that both adhesives were able to maintain the hybrid layer quality with no cracks (Figure 1).

Adhesive systems without the application of hydrophobic compound as last step tends to present higher hydrolytic degradation and bond instability because they are semipermeable membranes ${ }^{48}$. Although the SU acquires hydrophobic characteristics due to the presence of MDP after its polymerization, the adhesive still absorbs more water compared to the two-step self-adhesives (separate bottles) because they have better hydrophobic characteristics in contrast to the one-step adhesives ${ }^{44}$.

In order to assess the state of deterioration or to predict the longevity of dental adhesives, clinical studies are clearly the best methods ${ }^{25,49}$. However, due to the difficulty of standardizing clinical studies, in-vitro tests are performed to simulate the clinical conditions. Therefore, by observing several different methods and comparing the results, it may be useful to understand the degradation process that occurs in intraoral conditions. Thus, methods such as water storage ${ }^{17,50}$ and thermal cycle ${ }^{42,51,52}$, are the most used forms of artificial aging. Hidari et al. ${ }^{42}$ (2020) compared water storage and thermal cycle methods and assessed statistical differences between the adhesives. The water storage has an accelerated aging potential due to the hydrolysis capacity of hydrophilic components of the adhesive and the host-derived proteases with collagenolytic activity ${ }^{53,54}$. Therefore, water storage for 12 months may show results that reflect what happens clinically.

The null hypothesis of this study that there was no difference on DBS between the adhesives and through the time was partially rejected and these results are related to the variables adopted. Therefore, it is necessary to carry out further tests and evaluate different adhesives and their different application steps clinically. The need for longterm evaluations is also needed.

Under the limitations of this in vitro study, it was possible to conclude that the MP adhesive showed higher values of $\mu$ TBS compared to SU in both times of storage tested.

\section{Clinical significances}

The integrity of the hybrid layer is important to the longevity of resin-based restorations. Testing different adhesive systems clarifies the mechanisms involved on the effectiveness of the bonding interface and allows better choice for the clinician.

\section{Acknowledgements}

This work was supported by Coordenação de Aperfeiçoamento de Pessoal de Nível Superior - Brasil (CAPES) - Finance Code 001 and Fundação de Amparo à Pesquisa de São Paulo (FAPESP) [process \#2014/19613-5].

\section{References}

1. Carrilho E, Cardoso M, Marques Ferreira M, Marto CM, Paula A, Coelho AS. 10-MDP based dental adhesives: adhesive interface characterization and adhesive stability-a systematic review. Materials (Basel). 2019 Mar 7;12(5):790. doi: 10.3390/ma12050790 
2. Hashimoto M, Hirose N, Kitagawa H, Yamaguchi S, Imazato S. Improving the durability of resindentin bonds with an antibacterial monomer MDPB. Dent Mater J. 2018 Jul;37(4):620-27. doi: 10.4012/dmj.2017-209.

3. Pucci CR, Gu LS, Zhang HY, Song Q, Xia VW, Davis LB, et al. Water-associated attributes in the contemporary dentin bonding milieu. J Dent. 2018 Jul;74:79-89. doi: 10.1016/j.jdent.2018.04.016.

4. Wagner A, Wendler M, Petschelt A, Belli R, Lohbauer U. Bonding performance of universal adhesives in different etching modes. J Dent. 2014 Jul;42(7):800-7. doi: 10.1016/j.jdent.2014.04.012.

5. Freitas PH, Giannini M, Franca R, Correr AB, Correr-Sobrinho L, Consani S. Correlation between bond strength and nanomechanical properties of adhesive interface. Clin Oral Investig. 2017 May;21(4):1055-62. doi: 10.1007/s00784-016-1847-7.

6. Inoue S, Koshiro K, Yoshida Y, De Munck J, Nagakane K, Suzuki K, et al. Hydrolytic stability of self-etch adhesives bonded to dentin. J Dent Res. 2005 Dec;84(12):1160-4. doi: $10.1177 / 154405910508401213$.

7. Breschi L, Mazzoni A, Nato F, Carrilho M, Visintini E, Tjaderhane L, et al. Chlorhexidine stabilizes the adhesive interface: a 2-year in vitro study. Dent Mater. 2010 Apr;26(4):320-5. doi: 10.1016/j.dental.2009.11.153.

8. Porto ICCM, Nascimento TG, Oliveira JMS, Freitas PH, Haimeur A, Franca R. Use of polyphenols as a strategy to prevent bond degradation in the dentin-resin interface. Eur J Oral Sci. 2018 Apr;126(2):146-58. doi: 10.1111/eos.12403.

9. Ferracane JL. Resin-based composite performance: Are there some things we can't predict? Dent Mater. 2013 Jan;29(1):51-8. doi: 10.1016/j.dental.2012.06.013.

10. Gaengler P, Hoyer I, Montag R, Gaebler P. Micromorphological evaluation of posterior composite restorations - a 10-year report. J Oral Rehabil. 2004 Oct;31(10):991-1000. doi: 10.1111/j.1365-2842.2004.01329.x.

11. Tekce N, Tuncer S, Demirci M, Balci S. Do matrix metalloproteinase inhibitors improve the bond durability of universal dental adhesives? Scanning. 2016 Dec;38(6):535-44. doi: 10.1002/sca.21293.

12. Tjaderhane L, Nascimento FD, Breschi L, Mazzoni A, Tersariol IL, Geraldeli S, et al. Optimizing dentin bond durability: control of collagen degradation by matrix metalloproteinases and cysteine cathepsins. Dent Mater. 2013 Jan;29(1):116-35. doi: 10.1016/j.dental.2012.08.004.

13. Chen C, Niu LN, Xie H, Zhang ZY, Zhou LQ, Jiao K, et al. Bonding of universal adhesives to dentine--Old wine in new bottles? J Dent. 2015 May;43(5):525-36. doi: 10.1016/j.jdent.2015.03.004.

14. Van Meerbeek B, De Munck J, Yoshida Y, Inoue S, Vargas M, Vijay P, et al. Buonocore memorial lecture. Adhesion to enamel and dentin: current status and future challenges. Oper Dent. 2003 May-Jun;28(3):215-35.

15. Van Meerbeek B, Yoshihara K, Yoshida Y, Mine A, De Munck J, Van Landuyt KL. State of the art of self-etch adhesives. Dent Mater. 2011 Jan;27(1):17-28. doi: 10.1016/j.dental.2010.10.023.

16. Abdalla Al, Feilzer AJ. Four-year water degradation of a total-etch and two selfetching adhesives bonded to dentin. J Dent. 2008 2008/08/01/;36(8):611-7. doi: https://doi.org/10.1016/j.jdent.2008.04.011.

17. Cruz J, Sousa B, Coito C, Lopes M, Vargas M, Cavalheiro A. Microtensile bond strength to dentin and enamel of self-etch vs. etch-and-rinse modes of universal adhesives. Am J Dent. 2019 Aug;32(4):174-82.

18. Munoz MA, Luque-Martinez I, Malaquias P, Hass V, Reis A, Campanha NH, et al. In vitro longevity of bonding properties of universal adhesives to dentin. Oper Dent. 2015 May-Jun;40(3):282-92. doi: 10.2341/14-055-L.

19. Wu Z, Zheng H, Ouyang Y, Li M, Zhang L, Su J, et al. Prime-and-rinse approach for improving the enamel micro-tensile bond strengths of self-etch adhesives. J Adhes Sci Technol. 2019 2019/04/18;33(8):871-85. doi: 10.1080/01694243.2018.1564524. 
20. Follak AC, Miotti LL, Lenzi TL, Rocha RO, Soares FZM. Degradation of multimode adhesive system bond strength to artificial caries-affected dentin due to water storage. Oper Dent. 2018 MarApr;43(2):E92-E101. doi: 10.2341/17-129-L.

21. Perdigao J, Sezinando A, Monteiro PC. Laboratory bonding ability of a multi-purpose dentin adhesive. Am J Dent. 2012 Jun;25(3):153-8.

22. Theobaldo JD, Catelan A, Rodrigues U, Marchi GM, Lima DANL, Aguiar FHB. Effect of Cigarette smoke on resin composite bond strength to enamel and dentin using different adhesive systems. Oper Dent. 2016 May-Jun;41(3):E57-E63. doi: 10.2341/15-056-L.

23. Yoshida Y, Nagakane K, Fukuda R, Nakayama Y, Okazaki M, Shintani H, et al. Comparative study on adhesive performance of functional monomers. J Dent Res. 2004 Jun;83(6):454-8. doi: 10.1177/154405910408300604.

24. Wang R, Shi Y, Li T, Pan Y, Cui Y, Xia W. Adhesive interfacial characteristics and the related bonding performance of four self-etching adhesives with different functional monomers applied to dentin. J Dent. 2017 Jul;62:72-80. doi: 10.1016/j.jdent.2017.05.010.

25. De Munck J, Van Landuyt K, Peumans M, Poitevin A, Lambrechts P, Braem M, et al. A critical review of the durability of adhesion to tooth tissue: Methods and results. J Dent Res. 2005 Feb;84(2):118-32 doi: $10.1177 / 154405910508400204$.

26. Liu Y, Tjaderhane L, Breschi L, Mazzoni A, Li N, Mao J, et al. Limitations in bonding to dentin and experimental strategies to prevent bond degradation. J Dent Res. 2011 Aug;90(8):953-68. doi: $10.1177 / 0022034510391799$.

27. Pashley DH, Tay FR, Carvalho RM, Rueggeberg FA, Agee KA, Carrilho M, et al. From dry bonding to water-wet bonding to ethanol-wet bonding. A review of the interactions between dentin matrix and solvated resins using a macromodel of the hybrid layer. Am J Dent. 2007 Feb;20(1):7-20.

28. Almeida Junior L, Lula ECO, Penha KJS, Correia VS, Magalhaes FAC, Lima DM, et al. Polymerization Shrinkage of Bulk Fill Composites and its Correlation with Bond Strength. Braz Dent J. 2018 May-Jun;29(3):261-7. doi: 10.1590/0103-6440201801838.

29. Belli S, Donmez N, Eskitascioglu G. The effect of C-factor and flowable resin or fiber use at the interface on microtensile bond strength to dentin. J Adhes Dent. 2006 Aug;8(4):247-53.

30. El-Sahn NA, El-Kassas DW, El-Damanhoury HM, Fahmy OM, Gomaa H, Platt JA. Effect of C-factor on microtensile bond strengths of low-shrinkage composites. Oper Dent. 2011 May-Jun;36(3):281-92. doi: 10.2341/10-105-L.

31. Han SH, Park SH. Incremental and Bulk-fill Techniques With Bulk-fill Resin Composite in Different Cavity Configurations. Oper Dent. 2018 Nov/Dec;43(6):631-41. doi: 10.2341/17-279-LR.

32. McLeod ME, Price RB, Felix CM. Effect of configuration factor on shear bond strengths of selfetch adhesive systems to ground enamel and dentin. Oper Dent. 2010 Jan-Feb;35(1):84-93. doi: 10.2341/09-075-L.

33. Nikolaenko SA, Lohbauer U, Roggendorf M, Petschelt A, Dasch W, Frankenberger R. Influence of c-factor and layering technique on microtensile bond strength to dentin. Dent Mater. 2004 Jul;20(6):579-85. doi: 10.1016/j.dental.2003.08.001.

34. Singh TV, Patil JP, Raju RVSC, Venigalla BS, Jyotsna SV, Neha B. Comparison of effect of C-Factor on bond strength to human dentin using different composite resin materials. J Clin Diagn Res. 2015 Aug;9(8):Zc88-Zc91. doi: 10.7860/Jcdr/2015/14026.6384.

35. Bim Junior O, Cebim MA, Atta MT, Machado CM, Francisconi-Dos-Rios LF, Wang L. Determining optimal fluorescent agent concentrations in dental adhesive resins for imaging the tooth/restoration interface. Microsc Microanal. 2017 Feb;23(1):122-30. doi: 10.1017/S143192761601271X.

36. Yazici AR, Celik C, Ozgunaltay G, Dayangac B. Bond strength of different adhesive systems to dental hard tissues. Oper Dent. 2007 Mar-Apr;32(2):166-72. doi: 10.2341/06-49. 
37. Tay FR, Pashley DH. Resin bonding to cervical sclerotic dentin: a review. J Dent. 2004 Mar;32(3):173-96. doi: 10.1016/j.jdent.2003.10.009.

38. Reis A, Loguercio AD, Schroeder M, Luque-Martinez I, Masterson D, Maia LC. Does the adhesive strategy influence the post-operative sensitivity in adult patients with posterior resin composite restorations? A systematic review and meta-analysis. Dent Mater. 2015 Sep;31(9):1052-67. doi: 10.1016/j.dental.2015.06.001.

39. Gamborgi GP, Loguercio AD, Reis A. Influence of enamel border and regional variability on durability of resin-dentin bonds. J Dent. 2007 May;35(5):371-6. doi: 10.1016/j.jdent.2006.11.005.

40. Memarpour M, Shafiei F, Razmjouei F, Soltani M. Shear bond strength and scanning electron microscopy characteristics of universal adhesive in primary tooth dentin: An in vitro study. Dent Res J (Isfahan). 2018 Jul-Aug;15(4):264-70.

41. Yoshihara K, Yoshida Y, Hayakawa S, Nagaoka N, Irie M, Ogawa T, et al. Nanolayering of phosphoric acid ester monomer on enamel and dentin. Acta Biomater. 2011 Aug;7(8):3187-95. doi: 10.1016/j. actbio.2011.04.026.

42. Hidari T, Takamizawa T, Imai A, Hirokane E, Ishii R, Tsujimoto A, et al. Role of the functional monomer 10-methacryloyloxydecyl dihydrogen phosphate in dentin bond durability of universal adhesives in etch-\&-rinse mode. Dent Mater J. 2020 Aug;39(4):616-23. doi: 10.4012/dmj.2019-154.

43. Zhang L, Wang W, Wang C, Li M, Wang Z, Su Z, et al. Interaction of ACP and MDP and its effect on dentin bonding performance. J Mech Behav Biomed Mater. 2019 Mar;91:301-8. doi: 10.1016/j.jmbbm.2018.12.017.

44. Pouyanfar H, Tabaii ES, Aghazadeh S, Nobari SPTN, Imani MM. Microtensile bond strength of composite to enamel using universal adhesive with/without acid etching compared to etch and rinse and self-etch bonding agents. Open Access Maced J Med Sci. 2018 6(11):2186-92. doi: 10.3889/oamjms.2018.427.

45. Marchesi G, Frassetto A, Mazzoni A, Apolonio F, Diolosà M, Cadenaro M, et al. Adhesive performance of a multi-mode adhesive system: 1-Year in vitro study. J Dent. 2014 2014/05/01/;42(5):603-12. doi: https://doi.org/10.1016/j.jdent.2013.12.008.

46. da Rosa WLD, Piva E, da Silva AF. Bond strength of universal adhesives: A systematic review and meta-analysis. J Dent. 2015 Jul;43(7):765-76. doi: 10.1016/j.jdent.2015.04.003.

47. Anchieta R, Oliveira F, Sundfeld R, Rahal V, Machado L, de Alexandre R, et al. Analysis of hybrid layer thickness, resin tag length and their correlation with microtensile bond strength using a total etch adhesive to intact dentin. Acta Odontol Latinoam. 2011 12/01;24:272-8.

48. Tay FR, Pashley DH, Suh BI, Carvalho RM, Itthagarun A. Single-step adhesives are permeable membranes. J Dent. 2002 Sep-Nov;30(7-8):371-82. doi: 10.1016/s0300-5712(02)00064-7.

49. Peumans M, De Munck J, Mine A, Van Meerbeek B. Clinical effectiveness of contemporary adhesives for the restoration of non-carious cervical lesions. A systematic review. Dent Mater. 2014 Oct;30(10):1089-103. doi: 10.1016/j.dental.2014.07.007.

50. Vermelho PM, Reis AF, Ambrosano GMB, Giannini M. Adhesion of multimode adhesives to enamel and dentin after one year of water storage. Clin Oral Investig. 2017 Jun;21(5):1707-15. doi: 10.1007/s00784-016-1966-1.

51. Mitsui FH, Peris AR, Cavalcanti AN, Marchi GM, Pimenta LA. Influence of thermal and mechanical load cycling on microtensile bond strengths of total and self-etching adhesive systems. Oper Dent. 2006 Mar-Apr;31(2):240-7. doi: 10.2341/05-20.

52. Dos Santos PA, Garcia PP, Palma-Dibb RG. Shear bond strength of adhesive systems to enamel and dentin. Thermocycling influence. J Mater Sci Mater Med. 2005 Aug;16(8):727-32. doi: 10.1007/s10856-005-2609-2. 
53. De Munck J, Van den Steen PE, Mine A, Van Landuyt KL, Poitevin A, Opdenakker G, et al. Inhibition of enzymatic degradation of adhesive-dentin interfaces. J Dent Res. 2009 Dec;88(12):1101-6. doi: $10.1177 / 0022034509346952$.

54. Pashley DH, Tay FR, Yiu C, Hashimoto M, Breschi L, Carvalho RM, et al. Collagen degradation by host-derived enzymes during aging. J Dent Res. 2004 Mar;83(3):216-21. doi: $10.1177 / 154405910408300306$. 